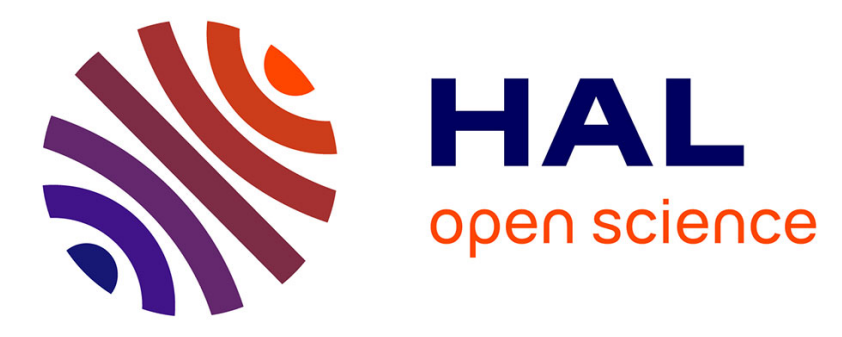

\title{
(all-E)- and (5Z)-Lycopene Display Similar Biological Effects on Adipocytes
}

\author{
Soumia Fenni, Julien Astier, Lauriane Bonnet, Esma Karkeni, Erwan \\ Gouranton, Lourdes Mounien, Charlène Couturier, Franck Tourniaire, Volker \\ Böhm, Habib Hammou, et al.
}

\section{To cite this version:}

Soumia Fenni, Julien Astier, Lauriane Bonnet, Esma Karkeni, Erwan Gouranton, et al.. (all-E)and (5Z)-Lycopene Display Similar Biological Effects on Adipocytes. Molecular Nutrition and Food Research, 2019, 63 (5), pp.1800788. 10.1002/mnfr.201800788 . hal-01998506

\section{HAL Id: hal-01998506 \\ https://hal-amu.archives-ouvertes.fr/hal-01998506}

Submitted on 29 Jan 2019

HAL is a multi-disciplinary open access archive for the deposit and dissemination of scientific research documents, whether they are published or not. The documents may come from teaching and research institutions in France or abroad, or from public or private research centers.
L'archive ouverte pluridisciplinaire HAL, est destinée au dépôt et à la diffusion de documents scientifiques de niveau recherche, publiés ou non, émanant des établissements d'enseignement et de recherche français ou étrangers, des laboratoires publics ou privés.

\section{(c)(1)}

Distributed under a Creative Commons Attribution| 4.0 International License 
(all-E)- and (5Z)-Lycopene display similar biological effects on adipocytes

Soumia Fenni ${ }^{1,2}$, Julien Astier ${ }^{1}$, Lauriane Bonnet ${ }^{1}$, Esma Karkeni ${ }^{1}$, Erwan Gouranton ${ }^{1}$, Lourdes Mounien $^{1}$, Charlene Couturier ${ }^{1}$, Franck Tourniaire ${ }^{1,3}$, Volker Böhm ${ }^{4}$, Habib Hammou ${ }^{2}$, JeanFrançois Landrier ${ }^{1,3}$

${ }^{1}$ Aix Marseille Univ, INSERM, INRA, C2VN, Marseille, France.

${ }^{2}$ Laboratoire de Physiologie de la Nutrition et Sécurité Alimentaire Département de Biologie, Faculté des Sciences de la Nature et de la Vie, Université Oran 1 Ahmed Benbella Oran, Algérie.

${ }^{3}$ CriBioM, Criblage Biologique Marseille, Faculté de Médecine de la Timone, Marseille, France.

${ }^{4}$ Institute of Nutritional Sciences, Friedrich-Schiller-Universität Jena, Dornburger Str. 25-29, 07743 Jena, Germany.

Corresponding author and person to whom reprint requests should be addressed:

Jean-François Landrier, C2VN, UMR 1263 INSERM / 1260 INRA/ AMU, 27 boulevard JeanMoulin, 13385 Marseille cedex 05, France. Phone: +33 4913242 75; e-mail: jean$\underline{\text { francois.landrier@univ-amu.fr }}$

Keywords: adipocyte, lycopene, inflammation, glucose uptake, PPARgamma 
Abbreviations: PPAR: peroxisome proliferator-activated receptor; TNF: Tumoral necrosis factor; CD36: cluster of differentiation 36; AKT: Protein kinase B; ChREBP: carbohydrate response element binding protein; NF-kB: nuclear factor $\mathrm{kB}$. 
Scope: Although about $90 \%$ of lycopene in dietary sources occurs in the linear all-trans conformation, a large proportion of the lycopene found in human tissues is of the cis-isomer type, notably (5Z)-lycopene. The biological effects of this (5Z) isomer have been underresearched. The aim of this study was to evaluate some biological functions of (5Z)-lycopene in adipocytes and to compare them with those of (all-E)-lycopene.

Methods and results: (all-E)- and (5Z)-Lycopene displayed strong similarities in global gene expression profile and biological pathways impacted. We identified PPAR signaling as a major actor mediating the effects of lycopene isomers. Transactivation assays confirmed the ability of both isomers to transactivate PPAR $\gamma$. In addition, the TNF $\alpha$-induced proinflammatory cytokine mRNA expression in 3T3-L1 adipocytes was reduced by both isomers, via a reduction in the phosphorylation levels of p65. Finally, lycopene isomers restored the TNF $\alpha$-blunted uptake of glucose by adipocytes, via a modulation of AKT phosphorylation.

Conclusion: These results show that lycopene isomers exert similar biological functions in adipocytes, linked to their ability to transactivate PPAR $\gamma$. These findings add to our knowledge of lycopene effects in adipocyte biology and point to the possible use of lycopene in the prevention of obesity-related disorders. 


\section{Introduction}

Lycopene is a lipophilic non-provitamin A carotenoid. It is responsible for the red color of various fruits and vegetables such as watermelon, papaya, guava and grapefruit, and is commonly found in tomatoes [1]. This carotenoid is well-known for its antioxidant properties [2], and has been reported to display anti-inflammatory effects in various cell types and tissues [3]. Notably, we have established that lycopene can decrease inflammatory markers in adipocytes, in macrophages and in vivo [4-7], which might alleviate disorders with a low-grade inflammatory background such as obesity, type II diabetes and cardiovascular disease (CVD) $[2,8]$. In humans, lycopene is mainly stored in adipose tissue, where it comprises more than a half of the total carotenoid concentration [9]. This storage is partly mediated by CD36 [10]. It has also been reported that higher lycopene intakes were associated with a lower waist circumference and visceral and subcutaneous fat mass [11], suggesting a beneficial impact of lycopene on adipose tissue / adipocyte metabolism, as recently highlighted [7].

As expected from its highly unsaturated structure, with 11 conjugated and two non-conjugated double bonds, several isomers of lycopene have been identified. Among these, (all-E)-lycopene is the most abundant isomer in fruits and vegetables (about 90\%). By contrast, a large proportion (approx. 1/3) of the lycopene isomers found in human serum and tissues is of the cis-isomer type [8, 12]. Several cis isomers have been identified, including (5Z)-, (9Z)-, (13Z), (15Z)-, (7Z)- and (11Z)-lycopene. Among these, (5Z)-lycopene was found to be the most stable [13]. Lycopene isomerization is assumed to take place in enterocytes [14], after absorption $[15,16]$, but the mechanism has never been described and it is unclear whether isomerization results from chemical and/or enzymatic processes, and whether it modulates the biological activity of lycopene.

Until now, most studies on the biological effects of lycopene have used (all-E)-lycopene. However, the presence of (5Z)-lycopene in plasma and its high stability suggest that this isomer 
might also mediate biological effects. The aim of this study was to evaluate some biological functions of (5Z)-lycopene in adipocytes and to compare these effects with those of (all-E)lycopene, which have already been documented. 


\section{Materials and methods}

\section{Chemicals}

Dulbecco's modified Eagle's medium (DMEM) was purchased from Life Technologies (Cergy-Pontoise, France). Fetal bovine serum (FBS) was obtained from PAA Laboratories (Les Mureaux, France). Isobutylmethylxanthine, dexamethasone, tetrahydrofuran containing 250 ppm butylated hydroxytoluene (THF/BHT) and insulin were purchased from Sigma-Aldrich (Saint-Quentin-Fallavier, France). (all-E)-Lycopene (purity > 95\%) was kindly provided by Dr. Catherine Caris-Veyrat (INRA, Avignon France). (5Z)-Lycopene was purchased from CaroteNature (Münsingen, Switzerland). TRIzol reagent, random primers and Moloney murine leukemia virus reverse transcriptase were obtained from Life Technologies (Saint-Aubin, France). SYBR Green reaction buffer was purchased from Eurogentec (Angers, France).

\section{Cell culture}

3T3-L1 Preadipocytes (ATCC, Manassas, VA) were seeded in $3.5 \mathrm{~cm}$ diameter dishes at a density of $15 \times 10^{4}$ cells/well. Cells were grown in DMEM supplemented with $10 \%$ FBS at $37^{\circ} \mathrm{C}$ in a $5 \% \mathrm{CO}_{2}$ humidified atmosphere, as previously reported [17, 18]. To induce differentiation, two-day postconfluent 3T3-L1 preadipocytes (Day 0) were stimulated for $48 \mathrm{~h}$ with $0.5 \mathrm{mM}$ isobutylmethylxanthine, $0.25 \mu \mathrm{M}$ dexamethasone, and $1 \mu \mathrm{g} / \mathrm{ml}$ insulin in DMEM supplemented with $10 \%$ FBS. The cultures were then treated with DMEM supplemented with $10 \%$ FBS and $1 \mu \mathrm{g} / \mathrm{mL}$ insulin. To examine the impact of lycopene isomers on gene expressions, 3T3-L1 adipocytes were incubated with $2 \mu \mathrm{M}$ of (all-E)- or (5Z)-lycopene dissolved in THF/BHT at $0.1 \%$ as previously reported [19] for $24 \mathrm{~h}$. Control received the vehicle (THF/BHT) alone. All treatments were performed on Day 8. The data are the mean of three independent experiments each performed in triplicate. To examine the anti-inflammatory 
effect of lycopene isomers, 3T3-L1 adipocytes were incubated with $2 \mu \mathrm{M}$ of (all-E)- or (5Z)lycopene or THF/BHT alone (Control) for $24 \mathrm{~h}$. These adipocytes were then incubated with TNF $\alpha(15 \mathrm{ng} / \mathrm{mL})$ for $3 \mathrm{~h}$. All treatments were performed on Day 8 . The data are the mean of three independent experiments each performed in triplicate.

\section{RNA isolation and qPCR}

Total cellular RNA was extracted using TRIzol reagent according to the manufacturer's instructions. cDNA was synthesized from $1 \mu \mathrm{g}$ of total RNA using random primers and Moloney murine leukemia virus reverse transcriptase [20]. Real-time quantitative RT-PCR analyses were performed using the Mx3005P Real-Time PCR System (Stratagene, La Jolla, CA) as previously described [21]. For each condition, the expression was quantified in duplicate, and the ribosomal protein $18 \mathrm{~S}$ mRNA was used as the endogenous control in the comparative cycle threshold (CT) method (2- $\Delta \Delta \mathrm{Ct})$ [22].

\section{Hybridization arrays and microarray data analysis}

RNA quality control was performed on an Agilent 2100 Bioanalyzer (Massy, France) with 6000 Nano Chips, according to the manufacturer's instructions and as previously reported [20, 23]. RNA from three independent experiments were pooled per treated group and hybridized to Agilent Whole Human Genome (4x44k; Massy, France). All labeling, hybridization, washing and scanning were performed as described in the manufacturer's protocol. Arrays were scanned with an Agilent Scanner (Massy, France). Data were extracted with Agilent Feature Extraction v9.5.3 and analyzed with Agilent GeneSpring GX v10.0 (Massy, France). Data were determined to be significant based on $p$-value $(p<0.05)$ and fold change (1.5). Lists of genes regulated by lycopene isomers are available on request from the corresponding author. Pathway analyses were performed with Metacore (http://www.genego.com/metacore.php). 


\section{PPAR $\gamma$ transactivation assay in vitro}

The reporter plasmid containing the gene for firefly luciferase under the control of four copies of the Gal4 binding site UAS was transfected into 3T3-L1 preadipocyte cells, together with plasmids coding CMX-Gal4 or CMX-Gal4-PPAR $\gamma$ and pGL4 plasmid coding the renilla luciferase. The transfection was performed using Lipofectamine 2000 (Invitrogen, Saint-Aubin, France). After overnight incubation with the transfection mixes $(1 \mu \mathrm{g}$ of plasmid, $0.9 \mu \mathrm{L}$ of Lipofectamine LTX and $1 \mu \mathrm{L}$ of Plus Reagent per well), according to the manufacturer's instructions, the medium was replaced by DMEM supplemented with $10 \%$ FBS and various concentrations $(0.1,0.2,1,2,10 \mu \mathrm{M})$ of (all-E)- or (5Z)-lycopene. After $24 \mathrm{~h}$ of treatment, the cells were lyzed and assayed for luciferase activity using a Dual-Glo luciferase assay system (Promega, Madison, WI), firefly luciferase activity was normalized to renilla luciferase. Roziglitazone ( 0.1 and $1 \mu \mathrm{M})$ was used as a positive control (data not shown). The transfection experiments were performed in triplicate and repeated three times independently.

\section{Glucose uptake}

The 3T3-L1 preadipocytes were differentiated into adipocytes for 8 days as previously described [24]. At Day 8, the cells were incubated with (all-E)- or (5Z)-lycopene $(2 \mu \mathrm{M})$ or THF/BHT alone (control) for $24 \mathrm{~h}$ with or without TNF $\alpha$ incubation $(15 \mathrm{ng} / \mathrm{mL})$ for $24 \mathrm{~h}$. One hour before the experiment, the cell medium was replaced by serum-free medium. The uptake of glucose was measured using a Uptake-Glo ${ }^{\text {TM }}$ glucose assay (Promega, Madison, WI). Briefly, the cells were incubated in PBS without insulin (unstimulated condition) or with 1 $\mu \mathrm{g} / \mathrm{mL}$ insulin for $30 \mathrm{~min}$ at $37^{\circ} \mathrm{C}$ (insulin-stimulated condition). After washing in PBS buffer, the cells were incubated in $500 \mu \mathrm{L}$ of PBS containing $1 \mathrm{mM}$ of 2-deoxyglucose (2DG) for 10 min. An acid detergent solution (Stop Buffer) was then added to lyze cells. The cells were 
transferred to a 96-well plate and a high-pH buffer solution (neutralization buffer) was added to neutralize the acid; $250 \mu \mathrm{L}$ of 2-deoxyglucose-6-phosphate (2DG6P) detection reagent was added to the sample wells, and the luminescence was measured after $1 \mathrm{~h}$. The uptake measurement was performed in triplicate and a standard curve of 2DG6P (1 mM) was used to convert the luminescence into 2DG6P concentration.

\section{NF-KB and AKT activation measurement}

To examine the involvement of the NF- $\kappa \mathrm{B}$ signaling pathway in 3T3-L1, the levels of p65 (Ser) phosphorylation were quantified using the ELISA InstantOne ${ }^{\mathrm{TM}} \mathrm{Kit}$ according to the manufacturer's instructions (eBiosciences SAS, Paris, France), as previously reported [25]. To examine the activation of the AKT signaling pathway, AKT phosphorylation and total AKT were measured in cells using ELISA InstantOne ${ }^{\mathrm{TM}}$ Kit according to the manufacturer's instructions (eBiosciences SAS, Paris, France).

\section{Statistical analysis}

The data are expressed as means \pm SEM. Significant differences between the control and treated groups were determined using ANOVA followed by the Tukey-Kramer post hoc test using Statview software: $p<0.05$ was considered statistically significant. 


\section{Results}

\section{(all-E)- and (5Z)-Lycopene modulate the transcriptome of 3T3-L1 adipocytes}

To study the impact of (all-E)- and (5Z)-lycopene in terms of global gene expression on adipocytes, microarray experiments were performed. 3T3-L1 adipocytes were incubated with (all-E)- or (5Z)-lycopene $(2 \mu \mathrm{M})$ for $24 \mathrm{~h}$. The impact of these treatments on the transcriptome was evaluated with a fold change filter of 1.5. As shown in Fig. 1A, 4821 genes were regulated by (all-E)-isomer (2392 upregulated, 1852 downregulated, $p<0.05$ ), and 3387 genes were regulated by (5Z)-isomer (1852 upregulated, 1535 downregulated, $p<0.05$ ). To compare these lists of genes, we made a Venn diagram that highlighted regulated genes in common or specifically for each isomer. Interestingly, 1941 genes were upregulated and downregulated by both (all-E)- and (5Z)-isomers (983 upregulated, 958 downregulated) (Fig. 1A). In addition, the fold change of genes regulated by (all-E) ( $y$-axis) was plotted against the fold change of genes regulated by (5Z) ( $x$-axis) (Fig. 1B). This scatter plot revealed a highly significant $(p<0.01)$ linear correlation between the two isomer conditions (Pearson coefficient of correlation 0.890). Pathway analysis using Metacore software showed that several pathways were significantly regulated by the two isomers (Tables 1 and 2). Both isoforms displayed impact on cytoskeleton, lipid metabolism, cell adhesion, immune response, AKT signaling and PPAR signaling. In addition, genes regulated by both (all-E)- and (5Z)-lycopene (983 upregulated, 958 downregulated, Fig. 1A) significantly impacted pathways related to cell adhesion, cytoskeleton, immune response, and lipid and glucose metabolism via several pathways such as regulation of lipid metabolism, insulin regulation of fatty acid metabolism, ChREBP signaling, PPAR signaling, and oxidative phosphorylation (Table 3).

(all-E)- and (5Z)-Lycopene transactivate PPAR $\gamma$ in vitro 
In order to assess the ability of (all-E)- and (5Z)-lycopene to transactivate PPAR $\gamma$, we performed transactivation assays in 3T3-L1 cells transiently transfected with a vector coding for the PPAR $\gamma$ ligand binding domain in the presence of various concentrations of (all-E)- and (5Z)-lycopene $(0.1,0.2,1,2,10 \mu \mathrm{M})$. The lowest concentration of (all-E)-lycopene did not transactivate $\operatorname{PPAR} \gamma$, whereas concentrations from $1 \mu \mathrm{M}$ to $10 \mu \mathrm{M}$ induced a dose response effect. (5Z)-Lycopene induced a significant transactivation of PPAR $\gamma$ from $0.2 \mu \mathrm{M}$. A strong effect was observed for the highest concentration of $10 \mu \mathrm{M}$ (Fig. 2).

(all-E)- and (5Z)-Lycopene decrease TNFa-mediated proinflammatory cytokine expression and NF- $\mathrm{KB}$ activation in 3T3-L1 adipocytes

We compared the ability of (all-E)- and (5Z)-lycopene to limit the inflammatory response triggered by TNF $\alpha$ treatment in 3T3-L1 adipocytes. For this purpose, 3T3-L1 cells were incubated with isomers $(2 \mu \mathrm{M})$ for $24 \mathrm{~h}$, followed by incubation with $\mathrm{TNF} \alpha(15 \mathrm{ng} / \mathrm{mL})$ for $3 \mathrm{~h}$. As expected, expression of monocyte chemoattractant protein-1 (Mcp1), interleukin-6 (Il6), chemokine (C-C motif) ligand 5 (Cc15), haptoglobin and serum amyloid A3 (Saa3), which are classical inflammatory markers, increased significantly by $90 \%, 80 \%, 95 \%, 99 \%$ and $63 \%$ respectively in the cells incubated in the presence of $\mathrm{TNF} \alpha$ compared with the control cells (Fig. 3). As previously reported, the pretreatment of cells with $2 \mu \mathrm{M}$ of (all-E)-lycopene significantly reduced Mcp1 expression by $16 \%$, Ccl5 by $27 \%$, and haptoglobin by $14 \%$. No significant differences were noted in the expression of Il6 and Saa3. Interestingly, the pretreatment of cells with (5Z)-lycopene significantly reduced the expression of Mcp1 by 21\%, Il6 by $50 \%$, Cc15 by $28 \%$, haptoglobin by $13 \%$ and Saa3 by $32 \%$ (Fig. 3 ).

$\mathrm{NF}-\kappa \mathrm{B}$ is a well-known transcription factor involved in the regulation of proinflammatory cytokines and chemokines in adipocytes [26]. We thus examined the involvement of the NF$\kappa \mathrm{B}$ signaling pathway in the mediation of anti-inflammatory effects of (all-E)- and (5Z)- 
lycopene in 3T3-L1 adipocytes. Cells were pretreated with (all-E)- or (5Z)-lycopene for $24 \mathrm{~h}$ followed by a 5 min incubation with TNF $\alpha$. As expected, the phosphorylation level of p65 was significantly increased under TNF $\alpha$ effect, whereas preincubation of cells with (all-E)- or (5Z)lycopene strongly limited the phosphorylation of p65 (Fig. 3).

(all-E)- and (5Z)-Lycopene improve 2-deoxyglucose uptake and AKT phosphorylation in

\section{T3-L1 adipocytes}

To determine the effect of (all-E)- and (5Z)-isomers on glucose metabolism, we measured 2deoxyglucose (2DG) uptake in 3T3-L1 adipocytes evaluated in the presence of TNF $\alpha$ alone or pretreated with (all-E)- and (5Z)-lycopene. The TNF $\alpha$ treatment led to a significant decrease in insulin-stimulated 2DG transport compared with control cells $(p<0.001)$ (Fig. 4A). Pretreatment with (all-E)- or (5Z)-lycopene followed by the TNF $\alpha$ treatment led to a significant increase in insulin-stimulated 2DG uptake compared with the TNF $\alpha$ condition $(p<0.001)$. The impact of these treatments on insulin signaling was evaluated at the phosphorylation level of AKT. The results showed that TNF $\alpha$ treatment decreased AKT phosphorylation $(p<0.01)$. Pretreatment with (all-E)- and (5Z)-lycopene followed by the TNF $\alpha$ treatment significantly restored AKT phosphorylation $(p<0.01)$ (Fig. 4B). 


\section{Discussion}

In this study, we compared the biological effects of two major isomers of lycopene, (all-E)- and (5Z)-lycopene. The first is the most abundant form in fruits and vegetables, but the second form is found in large amounts in plasma. Interestingly, both isomers are found in adipose tissue, where their concentrations have been evaluated at 0.9 and $1 \mu \mathrm{M}$ for (all-E) and (5Z)-lycopene [9], but data on their respective biological effects are scant.

Firstly, we determined the impact of (all-E)- and (5Z)-lycopene $(2 \mu \mathrm{M}$, which is in the range of concentrations found in adipose tissue) on gene expression in 3T3-L1 cells. Importantly, the (all-E)-isomer exhibited more pronounced effects in gene regulation than did (5Z)-lycopene. Such discrepancies could be due to different abilities of the two isomers to activate various signaling pathways or nuclear receptors: it has been established that all-trans lycopene transactivates RAR [27], but no data are available for /5Z)-lycopene. This is also the case for many other transcription factors such as Nrf2 [28]. In addition, we cannot exclude the possibility that (all-E) and (5-Z)-lycopene are differentially taken up by adipocytes as previously reported in enterocytes [15], or are differentially metabolized by enzymes such as $\mathrm{BCO} 2$ (expressed in 3T3-L1 cells; persona data), which is known to display a cleavage activity toward (5Z) but not toward (all-E) lycopene [29]. Nevertheless, a large proportion of genes are regulated by both isomers (1941 genes, Fig. 1), suggesting that common signaling pathways are involved. In evidence, pathway analysis of genes regulated by (all-E)- and (5Z)-isomers revealed a large overlap in pathways impacted (Table 2 and 3). This is notably the case for pathways related to lipid and glucose metabolism (regulation of lipid metabolism, regulation of insulin and fatty acid metabolism, oxidative phosphorylation, AKT signaling, etc.) and to immunity and transcription of PPAR. Moreover, these pathways were found to be regulated by genes commonly regulated by both (all-E)- and (5Z)-isomers (Table 3), suggesting that these pathways correspond to a similar pattern of gene regulation of the two isomers. Interestingly, 
these data strongly suggest a role of PPAR in the biological effect of lycopene isomers: the pathway "transcription_PPAR pathway" is activated by both isomers, and it is well established that this nuclear receptor is involved in various pathways found to be regulated in the present study. Peroxisome proliferator-activated receptor $\gamma(\operatorname{PPAR} \gamma)$, the main PPAR isoform in adipocytes, belongs to the superfamily of transcription nuclear receptors [30, 31]. PPAR $\gamma$ forms a heterodimer with retinoid $\mathrm{X}$ receptor $(\mathrm{RXR})$ that binds to a peroxisome proliferatorresponsive element (PPRE) in the regulatory domain of target genes, thereby affecting their expression [32]. PPAR $\gamma$ is known to be an important stimulator of adipogenesis $[33,34]$, and a potent modulator of insulin sensitivity [35], lipogenesis and adipocyte differentiation [36-38]. It also displays anti-inflammatory activity and is involved in metabolic homeostasis [30].

Based on these observations, we investigated in detail the impact of (all-E)- and (5Z)-lycopene on (i) PPAR $\gamma$ transactivation, (ii) inflammatory process and (iii) glucose uptake in adipocytes. We demonstrated that both lycopene isomers transactivated PPAR $\gamma$ in vitro in adipocytes. These results are consistent with previous reports demonstrating that lycopene and extracts of tomato were able to induce PPAR $\gamma$ dose-dependently [39], along with other carotenoids such as bixin and norbixin [40].

Since the activation of PPAR $\gamma$ is associated with anti-inflammatory effects [41], we assessed the effect of (all-E)- and (5Z)-lycopene on the adipocyte inflammatory status. To this end, TNF$\alpha$, a major mediator of obesity-related inflammation [42], was used to induce a low-grade inflammation in adipocytes. (all-E)- and (5Z)-Lycopene displayed an anti-inflammatory effect by decreasing the TNF $\alpha$-mediated expression of genes encoding pro-inflammatory markers such as cytokines (Il6), acute phase proteins (Saa3, haptoglobin) and chemokines (Ccl5, Mcp1). This downregulation of numerous proinflammatory markers mediated by lycopene isomers is associated with a strong limitation in the phosphorylation of p65 (Fig. 3), leading to a 
deactivation of the NF- $\kappa \mathrm{B}$ signaling. Thus it is highly probable that transactivation of PPAR $\gamma$ mediated the anti-inflammatory effect of (all-E)- and (5Z)-lycopene via the dephosphorylation of p65. Such an effect could be due to the impact of PPAR $\gamma$ activation on early events in the NF- $\mathrm{KB}$ signaling such as IKK phosphorylation, as previously demonstrated [4]. However, the precise molecular mechanism governing this deactivation of $\mathrm{NF}-\kappa \mathrm{B}$ signaling requires further investigation, since many mechanisms could be involved [43].

Also of note is the involvement of cytokines and chemokines in cardiometabolic disorders, such as insulin resistance and type II diabetes; all proinflammatory substances studied have been linked to inflammatory-mediated insulin resistance in metabolic tissues including the liver, skeletal muscles and adipose tissue [44]. In adipocytes, these substances are able to impair insulin sensitivity via several mechanisms, including direct interaction with insulin signaling via the modulation of the phosphorylation level of key players such as IRS1 [45]. We therefore hypothesized that the decrease in proinflammatory cytokines and chemokines reported with lycopene isomers would have a beneficial effect on adipocyte insulin sensitivity and glucose uptake. In evidence, we showed that lycopene isomers restored the TNF $\alpha$-mediated decrease in glucose uptake and AKT phosphorylation in adipocytes. These results are fully consistent with the well-established effects of PPAR $\gamma$ agonists (including thiazolidinediones) in increasing glucose uptake in adipocytes and subsequent AKT signaling [46]. We note that these properties are largely due to the ability of the PPAR $\gamma$ agonists to block the inflammatory process responsible for insulin resistance [47, 48].

Altogether, results generated by a transcriptomic and bioinformatics-coupled approach, highlight the ability of (all-E)- and (5Z)-lycopene to transactivate PPAR $\gamma$, leading to a modulation of inflammatory tone and a subsequent favorable impact on glucose uptake and insulin sensitivity in adipocytes. This study provides new data for the comparison of (all-E)- 
and (5Z)-lycopene in terms of biological activity, and reveals that these substances display similar effects, at least in adipocytes. Our findings add to current knowledge on the effects of lycopene on adipocyte biology, and open new perspectives for using lycopene isomers in the prevention of obesity-related health disorders. 
Conflict of interest statement: The authors have nothing to disclose. 


\section{Legends for figures}

Figure 1. Comparison of genes regulated by (all-E)- and (5Z)-lycopene in 3T3-L1 adipocytes. (A) Venn diagrams represent the number of significantly $(p<0.05)$ upregulated or downregulated genes in 3T3-L1 adipocytes due to (all-E)- or (5Z)-lycopene treatments. 3T3L1 adipocytes were incubated with (all-E)-lycopene $(2 \mu \mathrm{M})$ or (5Z)-lycopene $(2 \mu \mathrm{M})$ or vehicle alone for $24 \mathrm{~h}$. RNA was extracted and hybridized on a whole-mouse genome microarray. Data were computed using Genespring GX10 (fold change filter 1.5). (B) Commonly regulated genes after treatment with (all-E) ( $y$-axis) and (5Z) ( $x$-axis) were plotted. The correlation line was drawn, and the Pearson correlation coefficient and the associated $p$-value were calculated with SPSS17.

Figure 2. Effect of (all-E)- and (5Z)-lycopene on the transactivation of PPAR $\gamma$. 3T3-L1 cells were transiently transfected with plasmids coding for TK-MH100x4-Luc, PPAR $\gamma$-GaL4 and renilla luciferase. Cells were treated for $24 \mathrm{~h}$ with various concentrations of (all-E)- and (5Z)lycopene. Renilla and firefly luciferase quantification were performed as described in Materials and methods. Values not assigned the same letter are significantly different, $p<0.05$

Figure 3. Relative expression of mRNA inflammatory genes. 3T3-L1 adipocytes were incubated with (all-E)- and (5Z)-lycopene $(2 \mu \mathrm{M})$ or vehicle alone for $24 \mathrm{~h}$, and then incubated with TNF $\alpha$ (15 ng/mL) for $3 \mathrm{~h}$ (A to E). RNAs were extracted and reverse transcribed with MMLV. Real-time PCR was performed using specific primers. 18S rRNA was used as the endogenous control. Effect of (all-E)- and (5Z)-lycopene on p65 phosphorylation (F). Cells were preincubated with (all-E)- and (5Z)-lycopene $(2 \mu \mathrm{M})$ or vehicle alone for $24 \mathrm{~h}$, and incubated with TNF $\alpha(15 \mathrm{ng} / \mathrm{mL})$ for $5 \mathrm{~min}$. Phosphorylation levels of p65 were evaluated by 
ELISA. Values are presented as mean \pm S.E.M. Values not assigned the same letter are significantly different, $p<0.05$.

Figure 4. Effect of (all-E)- and (5Z)-lycopene on insulin-stimulated glucose uptake in 3T3-L1 adipocytes. (A) Cells were preincubated with (all-E)- and (5Z)-lycopene $(2 \mu \mathrm{M})$ or vehicle alone for $24 \mathrm{~h}$, and incubated with $\mathrm{TNF} \alpha(15 \mathrm{ng} / \mathrm{mL})$ for $30 \mathrm{~min}$. Glucose uptake was monitored as reported in Materials and methods. Effect of (all-E)- and (5Z)-lycopene on phosphorylation of AKT. (B) Cells were preincubated with (all-E)- and (5Z)-lycopene $(2 \mu \mathrm{M})$ or vehicle alone for $24 \mathrm{~h}$, and incubated with TNFa $(15 \mathrm{ng} / \mathrm{mL})$ for $5 \mathrm{~min}$. Phosphorylated and total levels of AKT were evaluated by ELISA, and the ratio between phosphorylated and total AKT was calculated. Values are presented as mean \pm S.E.M. Values not assigned the same letter are significantly different, $p<0.05$. 


\section{References}

[1] Rao, A. V., Ray, M. R., Rao, L. G., Lycopene. Adv Food Nutr Res 2006, 51, 99-164.

[2] Muller, L., Caris-Veyrat, C., Lowe, G., Bohm, V., Lycopene and Its Antioxidant Role in the Prevention of Cardiovascular Diseases-A Critical Review. Crit Rev Food Sci Nutr 2015, 56, 1868-1879.

[3] Wang, X. D., Lycopene metabolism and its biological significance. Am J Clin Nutr 2012, 96, 1214S$1222 \mathrm{~S}$.

[4] Gouranton, E., Thabuis, C., Riollet, C., Malezet-Desmoulins, C., El Yazidi, C., Amiot, M. J., Borel, P., Landrier, J. F., Lycopene inhibits proinflammatory cytokine and chemokine expression in adipose tissue. J Nutr Biochem 2011, 22, 642-648.

[5] Gouranton, E., Aydemir, G., Reynaud, E., Marcotorchino, J., Malezet, C., Caris-Veyrat, C., Blomhoff, R., Landrier, J. F., Ruhl, R., Apo-10'-lycopenoic acid impacts adipose tissue biology via the retinoic acid receptors. Biochim Biophys Acta 2011, 1811, 1105-1114.

[6] Marcotorchino, J., Romier, B., Gouranton, E., Riollet, C., Gleize, B., Malezet-Desmoulins, C., Landrier, J. F., Lycopene attenuates LPS-induced TNF-alpha secretion in macrophages and inflammatory markers in adipocytes exposed to macrophage-conditioned media. Mol Nutr Food Res 2012, 56, 725-732.

[7] Fenni, S., Hammou, H., Astier, J., Bonnet, L., Karkeni, E., Couturier, C., Tourniaire, F., Landrier, J. F., Lycopene and tomato powder supplementation similarly inhibit high-fat diet induced obesity, inflammatory response, and associated metabolic disorders. Mol Nutr Food Res 2017.

[8] Story, E. N., Kopec, R. E., Schwartz, S. J., Harris, G. K., An update on the health effects of tomato lycopene. Annu Rev Food Sci Technol 2010, 1, 189-210.

[9] Chung, H. Y., Ferreira, A. L., Epstein, S., Paiva, S. A., Castaneda-Sceppa, C., Johnson, E. J., Sitespecific concentrations of carotenoids in adipose tissue: relations with dietary and serum carotenoid concentrations in healthy adults. Am J Clin Nutr 2009, 90, 533-539.

[10] Moussa, M., Gouranton, E., Gleize, B., Yazidi, C. E., Niot, I., Besnard, P., Borel, P., Landrier, J. F., CD36 is involved in lycopene and lutein uptake by adipocytes and adipose tissue cultures. Mol Nutr Food Res 2011, 55, 578-584.

[11] Sluijs, I., Beulens, J. W., Grobbee, D. E., van der Schouw, Y. T., Dietary carotenoid intake is associated with lower prevalence of metabolic syndrome in middle-aged and elderly men. $J$ Nutr 2009, 139, 987-992.

[12] Moran, N. E., Cichon, M. J., Riedl, K. M., Grainger, E. M., Schwartz, S. J., Novotny, J. A., Erdman, J. W., Jr., Clinton, S. K., Compartmental and noncompartmental modeling of (1)(3)C-lycopene absorption, isomerization, and distribution kinetics in healthy adults. Am J Clin Nutr 2015, 102, 14361449.

[13] Chasse, G. A., Mak, M. L., Deretey, E., Farkas, I., Torday, L. L., Papp, J. G., Sarma, D. S. R., Agarwal, A., Chakravarthi, S., Agarwal, S., Rao, A. V., An ab initio computational study on selected lycopene isomers. J Mol Struc-Theochem 2001, 571, 27-37.

[14] Richelle, M., Sanchez, B., Tavazzi, I., Lambelet, P., Bortlik, K., Williamson, G., Lycopene isomerisation takes place within enterocytes during absorption in human subjects. Br J Nutr 2010, 103, 1800-1807.

[15] Moussa, M., Landrier, J. F., Reboul, E., Ghiringhelli, O., Comera, C., Collet, X., Frohlich, K., Bohm, V., Borel, P., Lycopene absorption in human intestinal cells and in mice involves scavenger receptor class B type I but not Niemann-Pick C1-like 1. J Nutr 2008, 138, 1432-1436.

[16] During, A., Dawson, H. D., Harrison, E. H., Carotenoid transport is decreased and expression of the lipid transporters SR-BI, NPC1L1, and ABCA1 is downregulated in Caco-2 cells treated with ezetimibe. J Nutr 2005, 135, 2305-2312.

[17] Landrier, J. F., Gouranton, E., El Yazidi, C., Malezet, C., Balaguer, P., Borel, P., Amiot, M. J., Adiponectin expression is induced by vitamin $\mathrm{E}$ via a peroxisome proliferator-activated receptor gamma-dependent mechanism. Endocrinology 2009, 150, 5318-5325. 
[18] Tourniaire, F., Musinovic, H., Gouranton, E., Astier, J., Marcotorchino, J., Arreguin, A., Bernot, D., Palou, A., Bonet, M. L., Ribot, J., Landrier, J. F., All-trans retinoic acid induces oxidative phosphorylation and mitochondria biogenesis in adipocytes. J Lipid Res 2016, 56, 1100-1109.

[19] Gouranton, E., Yazidi, C. E., Cardinault, N., Amiot, M. J., Borel, P., Landrier, J. F., Purified lowdensity lipoprotein and bovine serum albumin efficiency to internalise lycopene into adipocytes. Food Chem Toxicol 2008, 46, 3832-3836.

[20] Karkeni, E., Bonnet, L., Astier, J., Couturier, C., Dalifard, J., Tourniaire, F., Landrier, J. F., All-transretinoic acid represses chemokine expression in adipocytes and adipose tissue by inhibiting NFkappaB signaling. J Nutr Biochem 2017, 42, 101-107.

[21] Landrier, J. F., Malezet-Desmoulins, C., Reboul, E., Marie Lorec, A., Josephe Amiot, M., Borel, P., Comparison of different vehicles to study the effect of tocopherols on gene expression in intestinal cells. Free Radic Res 2008, 42, 523-530.

[22] Livak, K. J., Schmittgen, T. D., Analysis of relative gene expression data using real-time quantitative PCR and the 2(-Delta Delta C(T)) Method. Methods 2001, 25, 402-408.

[23] Landrier, J. F., Gouranton, E., Reboul, E., Cardinault, N., El Yazidi, C., Malezet-Desmoulins, C., Andre, M., Nowicki, M., Souidi, M., Borel, P., Vitamin E decreases endogenous cholesterol synthesis and apo-Al-mediated cholesterol secretion in Caco-2 cells. J Nutr Biochem 2010, 21, 1207-1213.

[24] Marcotorchino, J., Gouranton, E., Romier, B., Tourniaire, F., Astier, J., Malezet, C., Amiot, M. J., Landrier, J. F., Vitamin $D$ reduces the inflammatory response and restores glucose uptake in adipocytes. Mol Nutr Food Res 2012, 56, 1771-1782.

[25] Karkeni, E., Marcotorchino, J., Tourniaire, F., Astier, J., Peiretti, F., Darmon, P., Landrier, J. F., Vitamin $D$ limits chemokine expression in adipocytes and macrophage migration in vitro and in male mice. Endocrinology 2015, 156, 1782-1793.

[26] Tourniaire, F., Romier-Crouzet, B., Lee, J. H., Marcotorchino, J., Gouranton, E., Salles, J., Malezet, C., Astier, J., Darmon, P., Blouin, E., Walrand, S., Ye, J., Landrier, J. F., Chemokine Expression in Inflamed Adipose Tissue Is Mainly Mediated by NF-kappaB. PLoS One 2013, 8, e66515.

[27] Aydemir, G., Carlsen, H., Blomhoff, R., Ruhl, R., Lycopene induces retinoic acid receptor transcriptional activation in mice. Mol Nutr Food Res 2012, 56, 702-712.

[28] Ben-Dor, A., Steiner, M., Gheber, L., Danilenko, M., Dubi, N., Linnewiel, K., Zick, A., Sharoni, Y., Levy, J., Carotenoids activate the antioxidant response element transcription system. Mol Cancer Ther 2005, 4, 177-186.

[29] Hu, K. Q., Liu, C., Ernst, H., Krinsky, N. I., Russell, R. M., Wang, X. D., The biochemical characterization of ferret carotene-9',10'-monooxygenase catalyzing cleavage of carotenoids in vitro and in vivo. J Biol Chem 2006, 281, 19327-19338.

[30] Wang, L., Waltenberger, B., Pferschy-Wenzig, E. M., Blunder, M., Liu, X., Malainer, C., Blazevic, T., Schwaiger, S., Rollinger, J. M., Heiss, E. H., Schuster, D., Kopp, B., Bauer, R., Stuppner, H., Dirsch, V. M., Atanasov, A. G., Natural product agonists of peroxisome proliferator-activated receptor gamma (PPARgamma): a review. Biochem Pharmacol 2014, 92, 73-89.

[31] Evans, R. M., Barish, G. D., Wang, Y. X., PPARs and the complex journey to obesity. Nat Med 2004, 10, 355-361.

[32] Berger, J., Moller, D. E., The mechanisms of action of PPARs. Annu Rev Med 2002, 53, 409-435.

[33] Barak, Y., Nelson, M. C., Ong, E. S., Jones, Y. Z., Ruiz-Lozano, P., Chien, K. R., Koder, A., Evans, R. M., PPAR gamma is required for placental, cardiac, and adipose tissue development. Mol Cell 1999, 4, 585-595.

[34] Farmer, S. R., Transcriptional control of adipocyte formation. Cell Metab 2006, 4, 263-273.

[35] Bennett, S. M., Agrawal, A., Elasha, H., Heise, M., Jones, N. P., Walker, M., Wilding, J. P., Rosiglitazone improves insulin sensitivity, glucose tolerance and ambulatory blood pressure in subjects with impaired glucose tolerance. Diabet Med 2004, 21, 415-422.

[36] Lehrke, M., Lazar, M. A., The many faces of PPARgamma. Cell 2005, 123, 993-999.

[37] Straus, D. S., Glass, C. K., Anti-inflammatory actions of PPAR ligands: new insights on cellular and molecular mechanisms. Trends Immunol 2007, 28, 551-558. 
[38] Christodoulides, C., Lagathu, C., Sethi, J. K., Vidal-Puig, A., Adipogenesis and WNT signalling. Trends Endocrinol Metab 2009, 20, 16-24.

[39] Gijsbers, L., van Eekelen, H. D., de Haan, L. H., Swier, J. M., Heijink, N. L., Kloet, S. K., Man, H. Y., Bovy, A. G., Keijer, J., Aarts, J. M., van der Burg, B., Rietjens, I. M., Induction of peroxisome proliferator-activated receptor gamma (PPARgamma)-mediated gene expression by tomato (Solanum lycopersicum L.) extracts. J Agric Food Chem 2013, 61, 3419-3427.

[40] Takahashi, N., Goto, T., Taimatsu, A., Egawa, K., Katoh, S., Kusudo, T., Sakamoto, T., Ohyane, C., Lee, J. Y., Kim, Y. I., Uemura, T., Hirai, S., Kawada, T., Bixin regulates mRNA expression involved in adipogenesis and enhances insulin sensitivity in 3T3-L1 adipocytes through PPARgamma activation. Biochem Biophys Res Commun 2009, 390, 1372-1376.

[41] Ricote, M., Li, A. C., Willson, T. M., Kelly, C. J., Glass, C. K., The peroxisome proliferator-activated receptor-gamma is a negative regulator of macrophage activation. Nature 1998, 391, 79-82.

[42] Hotamisligil, G. S., Shargill, N. S., Spiegelman, B. M., Adipose expression of tumor necrosis factoralpha: direct role in obesity-linked insulin resistance. Science 1993, 259, 87-91.

[43] Wen, X., Li, Y., Liu, Y., Opposite action of peroxisome proliferator-activated receptor-gamma in regulating renal inflammation: functional switch by its ligand. J Biol Chem 2010, 285, 29981-29988.

[44] Gregor, M. F., Hotamisligil, G. S., Inflammatory mechanisms in obesity. Annu Rev Immunol 2011, $29,415-445$.

[45] Hotamisligil, G. S., Peraldi, P., Budavari, A., Ellis, R., White, M. F., Spiegelman, B. M., IRS-1mediated inhibition of insulin receptor tyrosine kinase activity in TNF-alpha- and obesity-induced insulin resistance. Science 1996, 271, 665-668.

[46] Nugent, C., Prins, J. B., Whitehead, J. P., Savage, D., Wentworth, J. M., Chatterjee, V. K., O'Rahilly, S., Potentiation of glucose uptake in 3T3-L1 adipocytes by PPAR gamma agonists is maintained in cells expressing a PPAR gamma dominant-negative mutant: evidence for selectivity in the downstream responses to PPAR gamma activation. Mol Endocrinol 2001, 15, 1729-1738.

[47] Diaz-Delfin, J., Morales, M., Caelles, C., Hypoglycemic action of thiazolidinediones/peroxisome proliferator-activated receptor gamma by inhibition of the c-Jun $\mathrm{NH}$-terminal kinase pathway.

Diabetes 2007, 56, 1865-1871.

[48] Moller, D. E., Berger, J. P., Role of PPARs in the regulation of obesity-related insulin sensitivity and inflammation. Int J Obes Relat Metab Disord 2003, 27 Suppl 3, S17-21. 
Table 1. Pathways regulated by (all-E)- lycopene.

\begin{tabular}{|c|c|c|}
\hline Map & Map Folders & p-Value \\
\hline $\begin{array}{l}\text { Cytoskeleton remodeling_Role of } \\
\text { PKA in cytoskeleton reorganisation }\end{array}$ & $\begin{array}{l}\text { Protein function/Kinases Regulatory } \\
\text { processes/Cytoskeleton remodeling }\end{array}$ & $1,071 \mathrm{E}-07$ \\
\hline $\begin{array}{l}\text { Cytoskeleton } \\
\text { remodeling_Cytoskeleton } \\
\text { remodeling }\end{array}$ & $\begin{array}{l}\text { Regulatory processes/Cytoskeleton } \\
\text { remodeling }\end{array}$ & $1,186 \mathrm{E}-07$ \\
\hline $\begin{array}{l}\text { Regulation of lipid metabolism } \\
\text { Stimulation of Arachidonic acid } \\
\text { production by ACM receptors }\end{array}$ & $\begin{array}{l}\text { Protein function/G-proteins/GPCR } \\
\text { Regulation of metabolism/Regulation } \\
\text { of lipid metabolism }\end{array}$ & $3,844 \mathrm{E}-03$ \\
\hline $\begin{array}{l}\text { Cytoskeleton remodeling_TGF, } \\
\text { WNT and cytoskeletal remodeling }\end{array}$ & $\begin{array}{l}\text { Regulatory processes/Cytoskeleton } \\
\text { remodeling }\end{array}$ & $9,321 \mathrm{E}-07$ \\
\hline $\begin{array}{l}\text { Regulation of lipid } \\
\text { metabolism_Insulin regulation of } \\
\text { glycogen metabolism }\end{array}$ & $\begin{array}{l}\text { Protein function/Hormones Regulation } \\
\text { of metabolism/Regulation of lipid } \\
\text { metabolism }\end{array}$ & $1,251 \mathrm{E}-02$ \\
\hline $\begin{array}{l}\text { Cell adhesion_Integrin-mediated } \\
\text { cell adhesion and migration }\end{array}$ & Regulatory processes/Cell adhesion & $1,295 \mathrm{E}-05$ \\
\hline
\end{tabular}




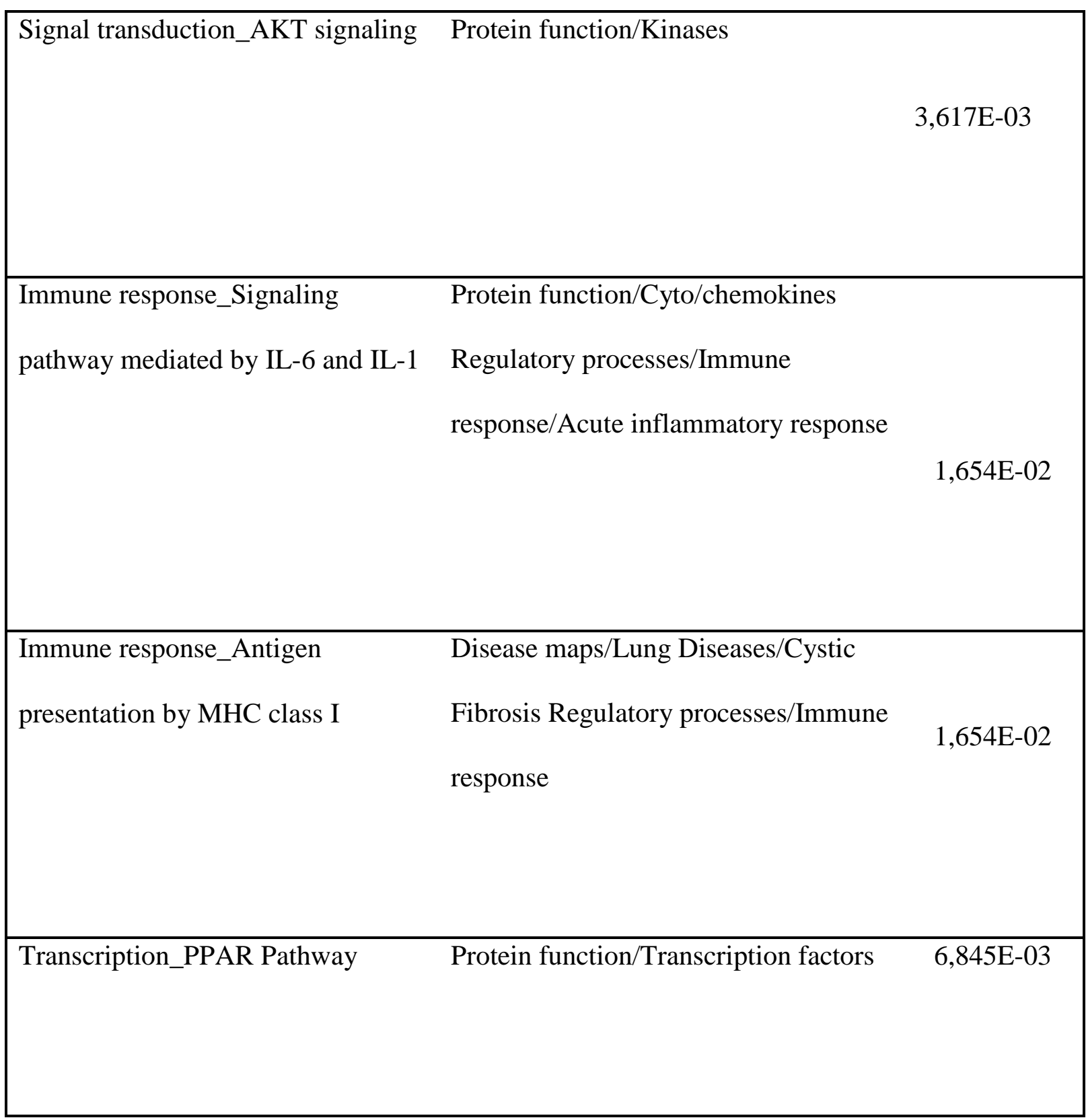


Table 2. Pathways regulated by (5Z)-lycopene.

\begin{tabular}{|c|c|c|}
\hline Map & Map Folders & p-Value \\
\hline $\begin{array}{l}\text { Cytoskeleton remodeling_Role of } \\
\text { PKA in cytoskeleton reorganisation }\end{array}$ & $\begin{array}{l}\text { Protein function/Kinases Regulatory } \\
\text { processes/Cytoskeleton remodeling }\end{array}$ & $1,071 \mathrm{E}-07$ \\
\hline $\begin{array}{l}\text { Cytoskeleton } \\
\text { remodeling_Cytoskeleton } \\
\text { remodeling }\end{array}$ & $\begin{array}{l}\text { Regulatory processes/Cytoskeleton } \\
\text { remodeling }\end{array}$ & $1,186 \mathrm{E}-07$ \\
\hline $\begin{array}{l}\text { Regulation of lipid metabolism } \\
\text { Stimulation of Arachidonic acid } \\
\text { production by ACM receptors }\end{array}$ & $\begin{array}{l}\text { Protein function/G-proteins/GPCR } \\
\text { Regulation of metabolism/Regulation } \\
\text { of lipid metabolism }\end{array}$ & $3,844 \mathrm{E}-03$ \\
\hline $\begin{array}{l}\text { Cytoskeleton remodeling_TGF, } \\
\text { WNT and cytoskeletal remodeling }\end{array}$ & $\begin{array}{l}\text { Regulatory processes/Cytoskeleton } \\
\text { remodeling }\end{array}$ & $9,321 \mathrm{E}-07$ \\
\hline $\begin{array}{l}\text { Regulation of lipid } \\
\text { metabolism_Insulin regulation of } \\
\text { glycogen metabolism }\end{array}$ & $\begin{array}{l}\text { Protein function/Hormones Regulation } \\
\text { of metabolism/Regulation of lipid } \\
\text { metabolism }\end{array}$ & $1,251 \mathrm{E}-02$ \\
\hline $\begin{array}{l}\text { Cell adhesion_Integrin-mediated } \\
\text { cell adhesion and migration }\end{array}$ & Regulatory processes/Cell adhesion & $1,295 \mathrm{E}-05$ \\
\hline
\end{tabular}




\begin{tabular}{|c|c|c|}
\hline Signal transduction_AKT signaling & Protein function/Kinases & $3,617 \mathrm{E}-03$ \\
\hline $\begin{array}{l}\text { Immune response_Signaling } \\
\text { pathway mediated by IL-6 and IL-1 }\end{array}$ & $\begin{array}{l}\text { Protein function/Cyto/chemokines } \\
\text { Regulatory processes/Immune } \\
\text { response/Acute inflammatory response }\end{array}$ & $1,654 \mathrm{E}-02$ \\
\hline $\begin{array}{l}\text { Immune response_Antigen } \\
\text { presentation by MHC class I }\end{array}$ & $\begin{array}{l}\text { Disease maps/Lung Diseases/Cystic } \\
\text { Fibrosis Regulatory processes/Immune } \\
\text { response }\end{array}$ & 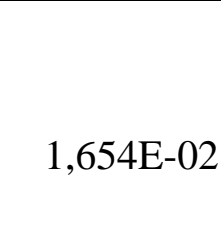 \\
\hline Transcription_PPAR Pathway & Protein function/Transcription factors & $6,845 \mathrm{E}-03$ \\
\hline
\end{tabular}


Table 3. Pathways regulated by (all-E) and (5-Z) isoforms of lycopene.

\begin{tabular}{|c|c|c|}
\hline Map & Map Folders & p-Value \\
\hline $\begin{array}{l}\text { Transcription_ChREBP regulation } \\
\text { pathway }\end{array}$ & $\begin{array}{l}\text { Protein function/G-proteins/GPCR } \\
\text { Protein function/Transcription factors }\end{array}$ & $2,086 \mathrm{E}-04$ \\
\hline $\begin{array}{l}\text { Cytoskeleton remodeling_Role of } \\
\text { PKA in cytoskeleton reorganisation }\end{array}$ & $\begin{array}{l}\text { Protein function/Kinases Regulatory } \\
\text { processes/Cytoskeleton remodeling }\end{array}$ & 1,969E-09 \\
\hline $\begin{array}{l}\text { Cell adhesion_Integrin-mediated } \\
\text { cell adhesion and migration }\end{array}$ & Regulatory processes/Cell adhesion & $8,004 \mathrm{E}-09$ \\
\hline $\begin{array}{l}\text { Cytoskeleton } \\
\text { remodeling_Fibronectin-binding } \\
\text { integrins in cell motility }\end{array}$ & $\begin{array}{l}\text { Regulatory processes/Cell adhesion } \\
\text { Regulatory processes/Cytoskeleton } \\
\text { remodeling }\end{array}$ & $6,236 \mathrm{E}-07$ \\
\hline $\begin{array}{l}\text { Immune response_IFN gamma } \\
\text { signaling pathway }\end{array}$ & $\begin{array}{l}\text { Protein function/Cyto/chemokines } \\
\text { Regulatory processes/Immune } \\
\text { response }\end{array}$ & $1,431 \mathrm{E}-02$ \\
\hline $\begin{array}{l}\text { Immune response_Antigen } \\
\text { presentation by MHC class I }\end{array}$ & $\begin{array}{l}\text { Disease maps/Lung Diseases/Cystic } \\
\text { Fibrosis Regulatory } \\
\text { processes/Immune response }\end{array}$ & $1,654 \mathrm{E}-02$ \\
\hline
\end{tabular}




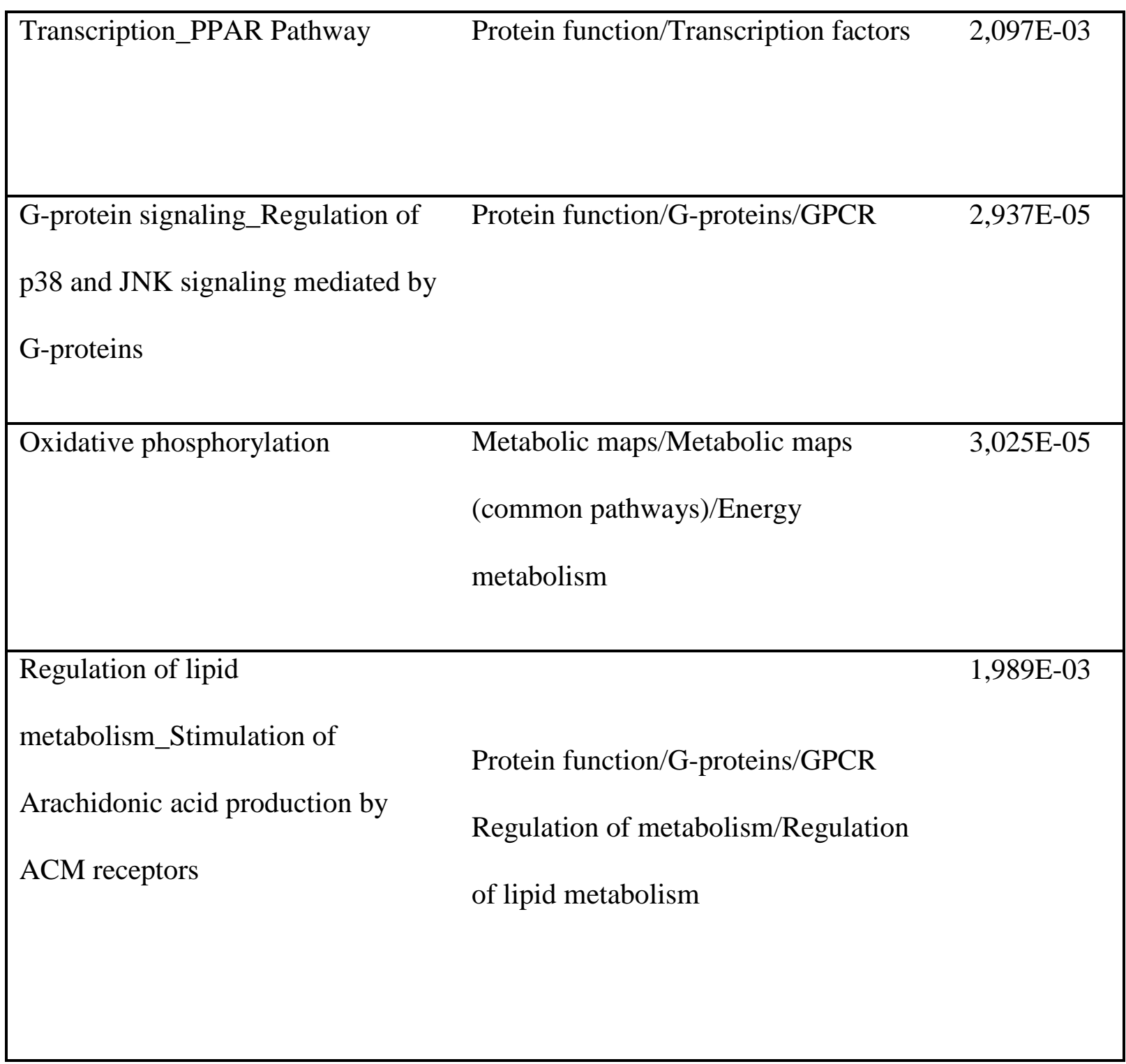


A Up-regulated genes

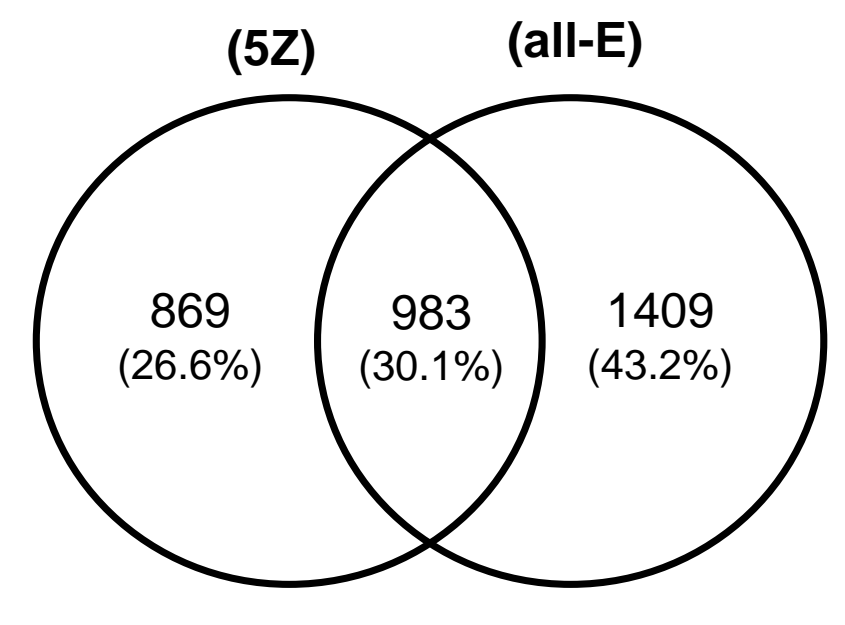

Down-regulated genes

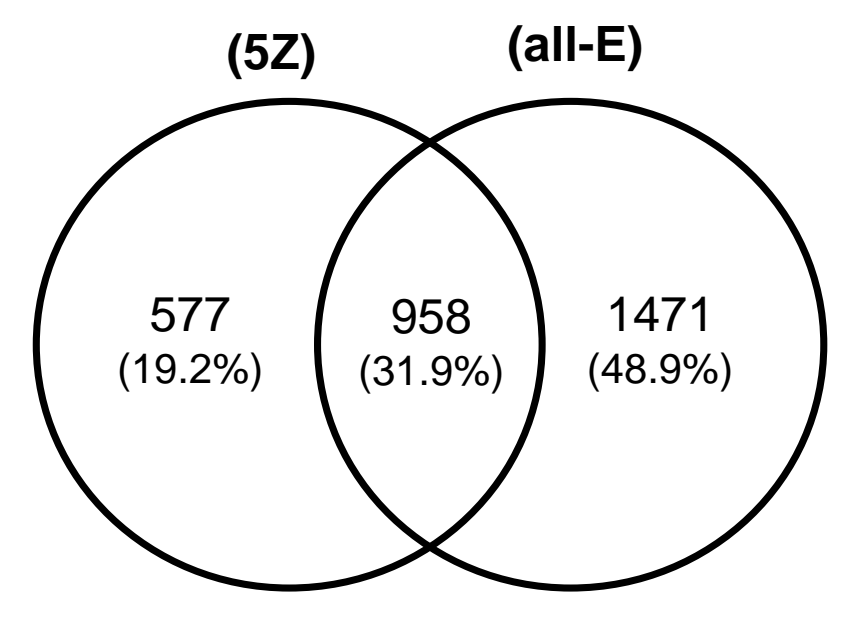

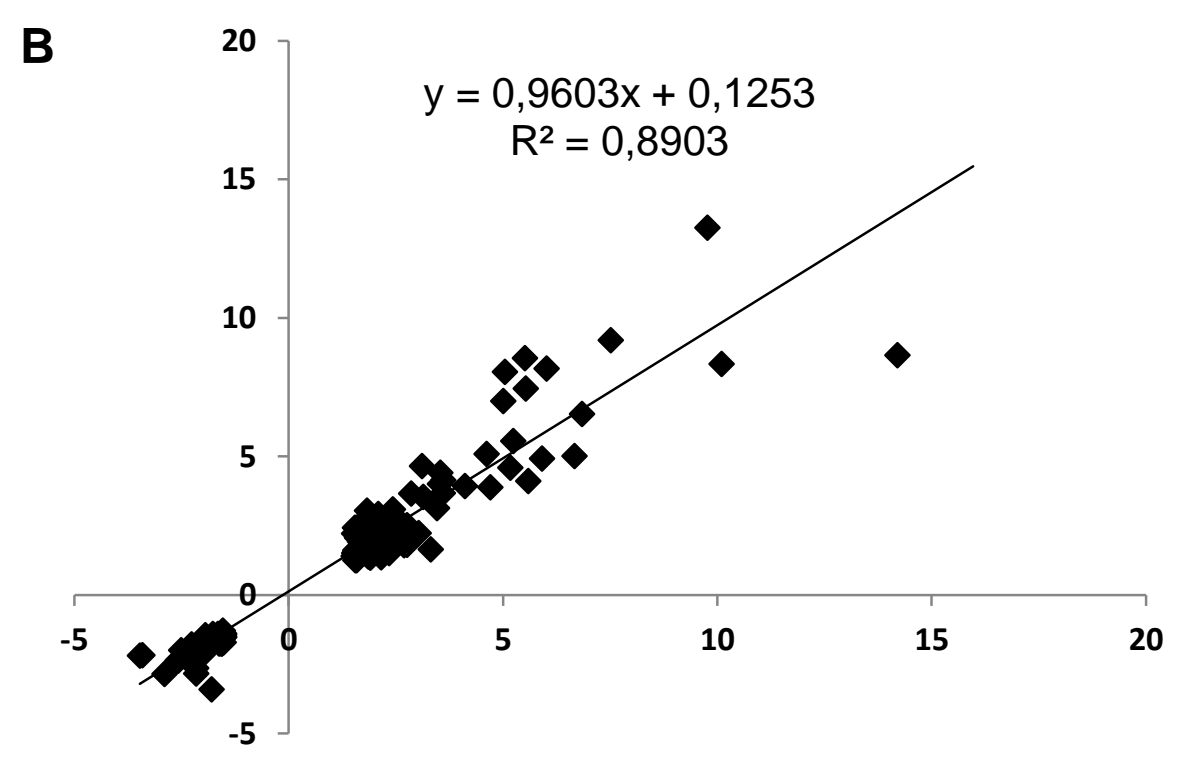


Figure 2

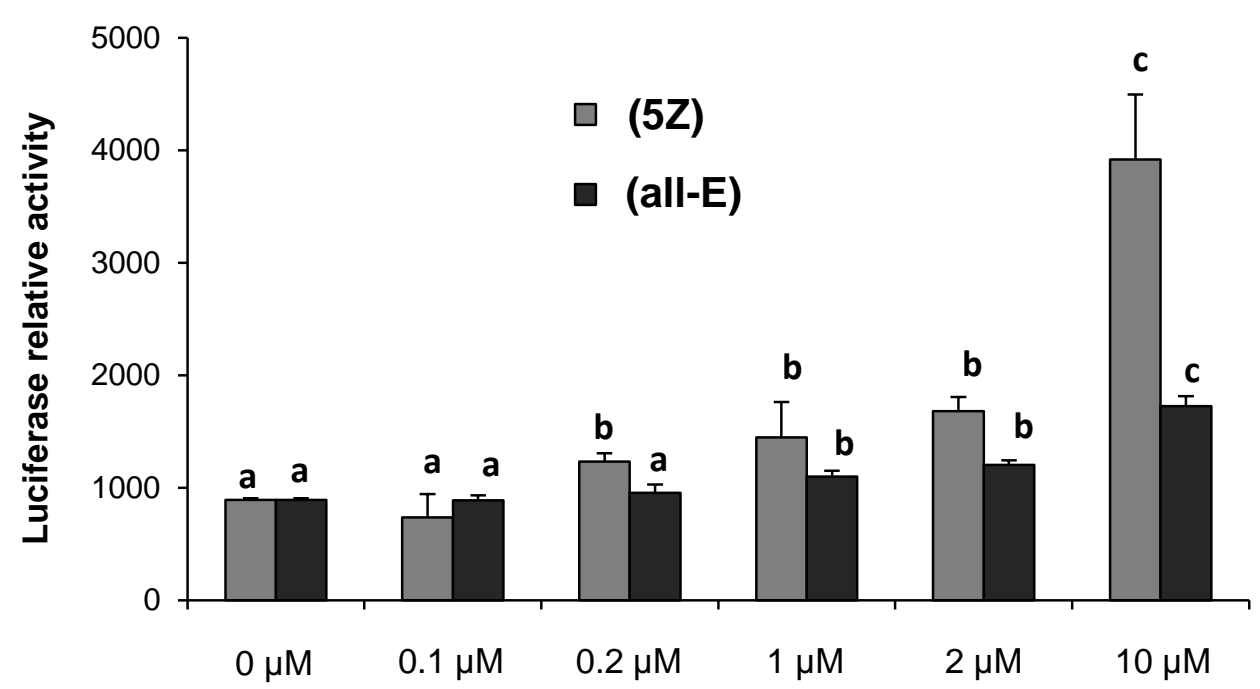


A

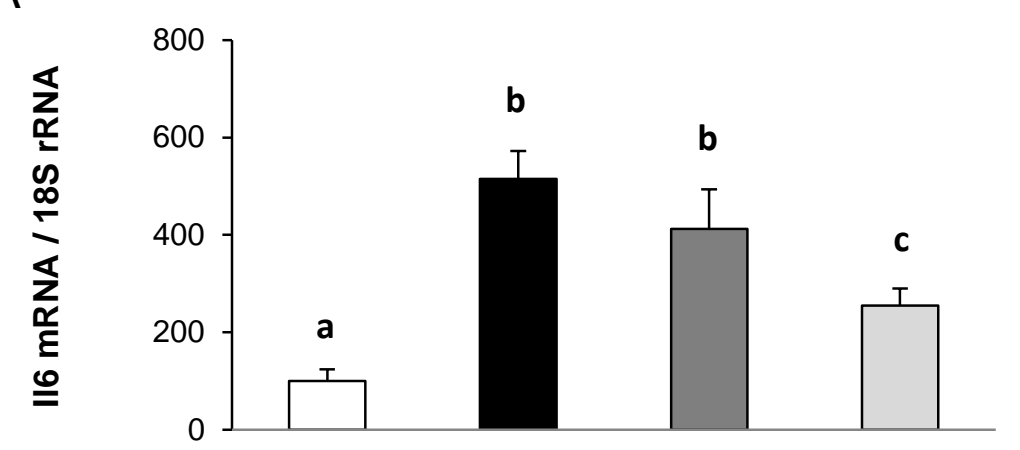

B

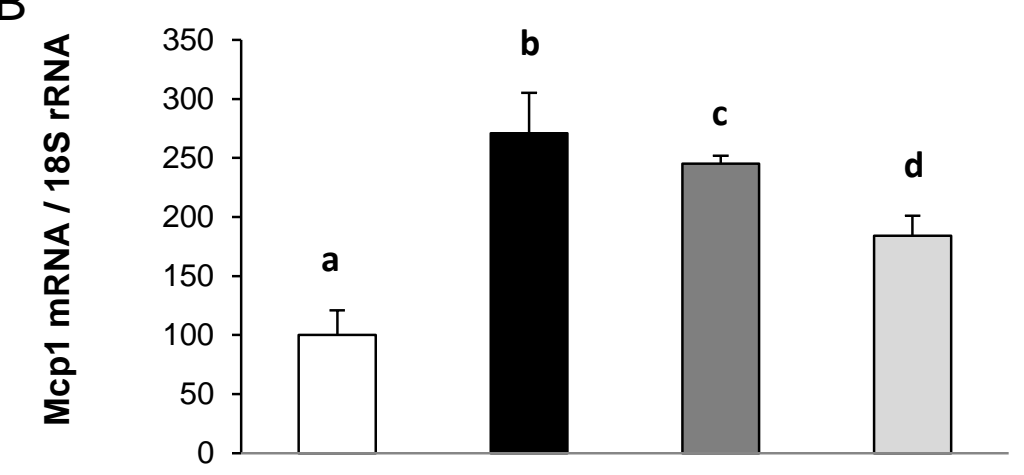

C

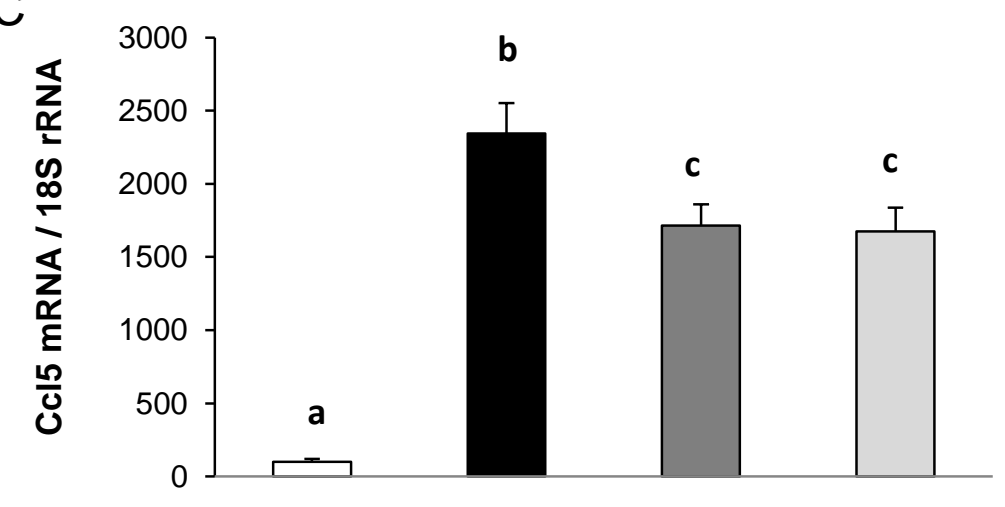

TNFa

(all-E)

(5Z)
D

Figure 3

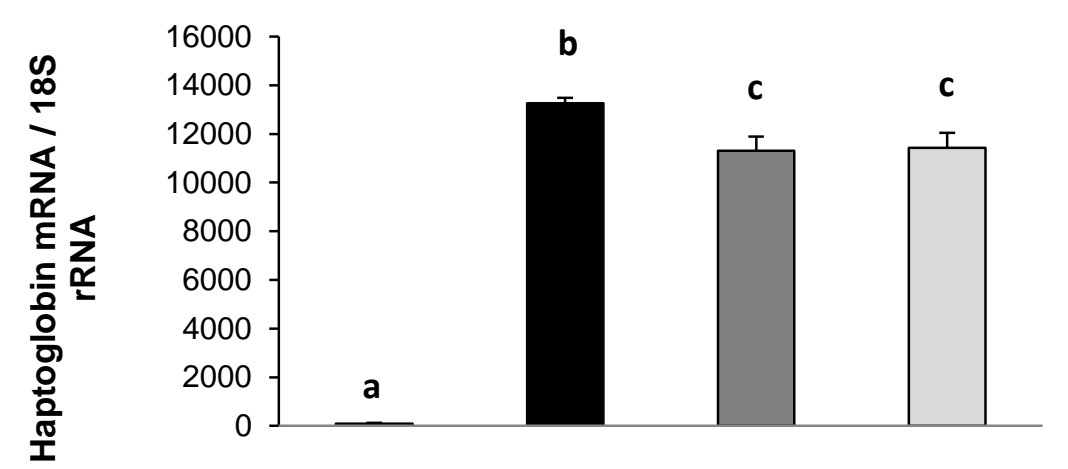

E

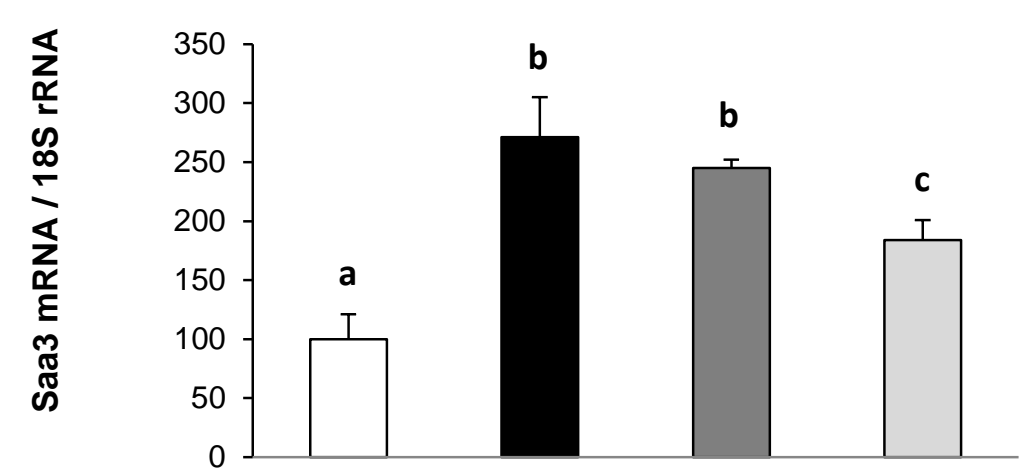

F

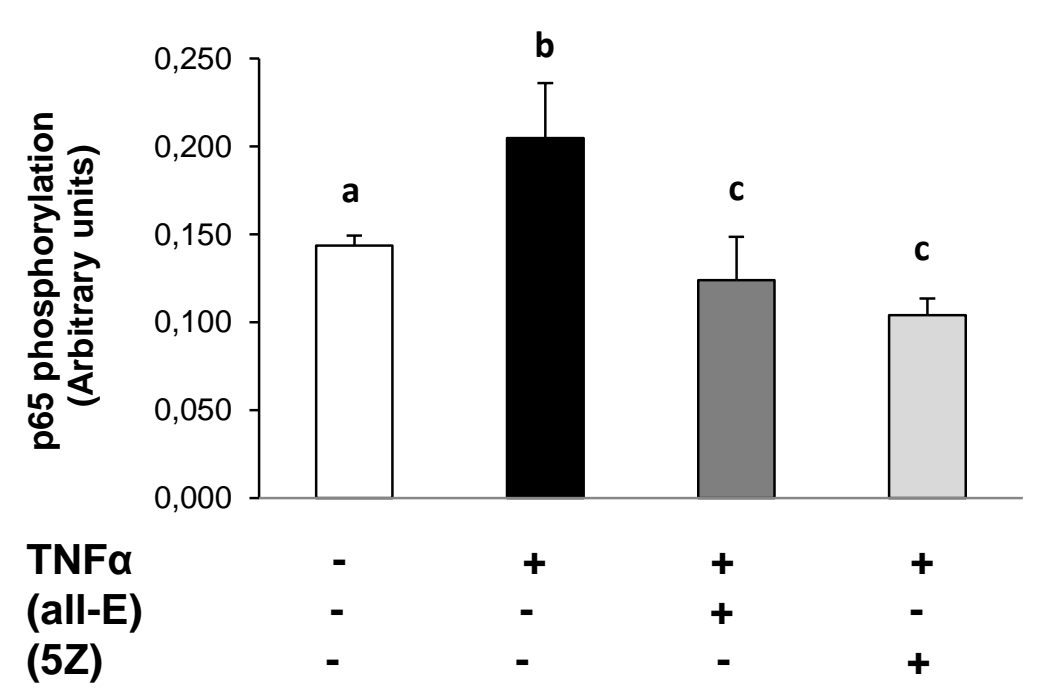


A

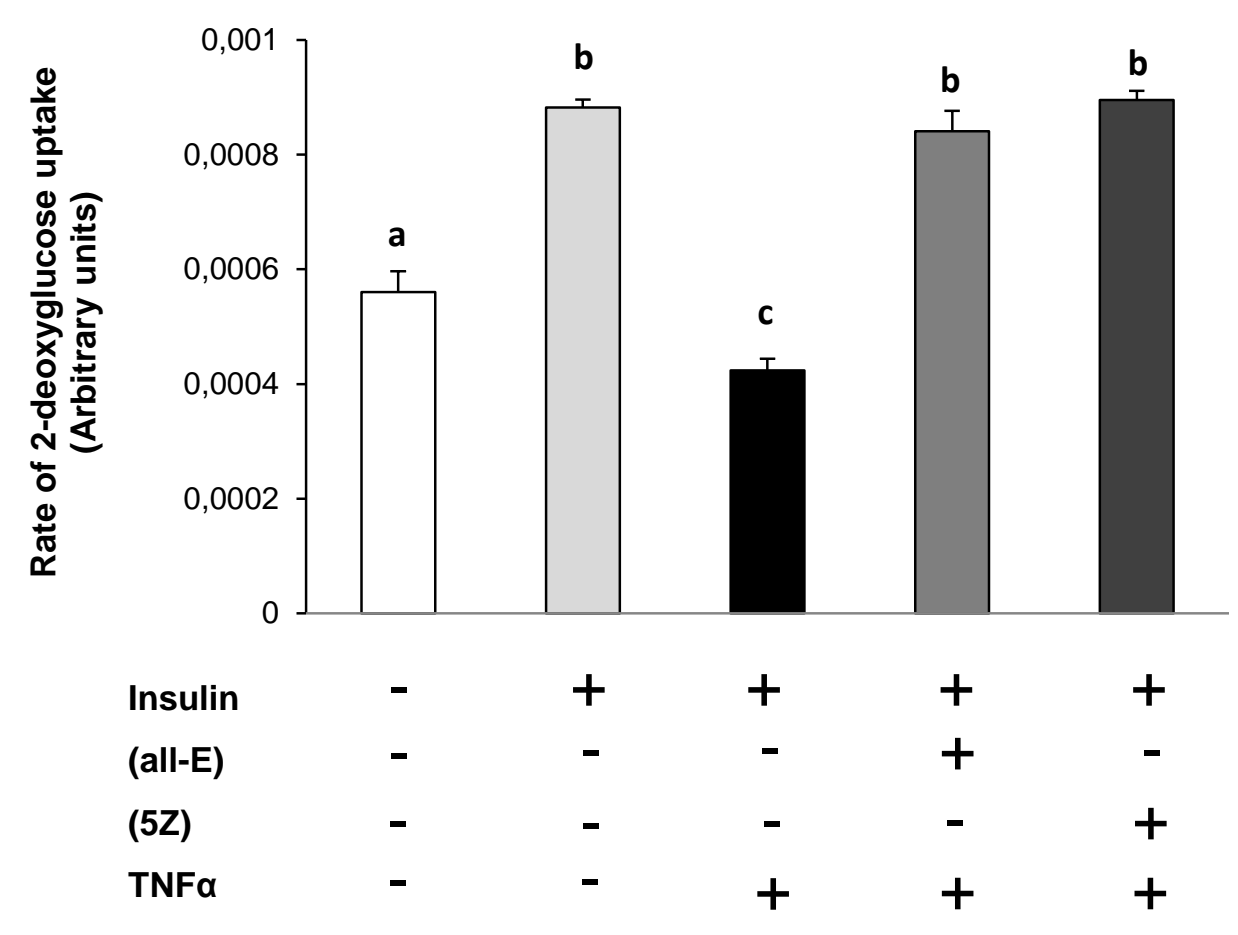

Figure 4

B

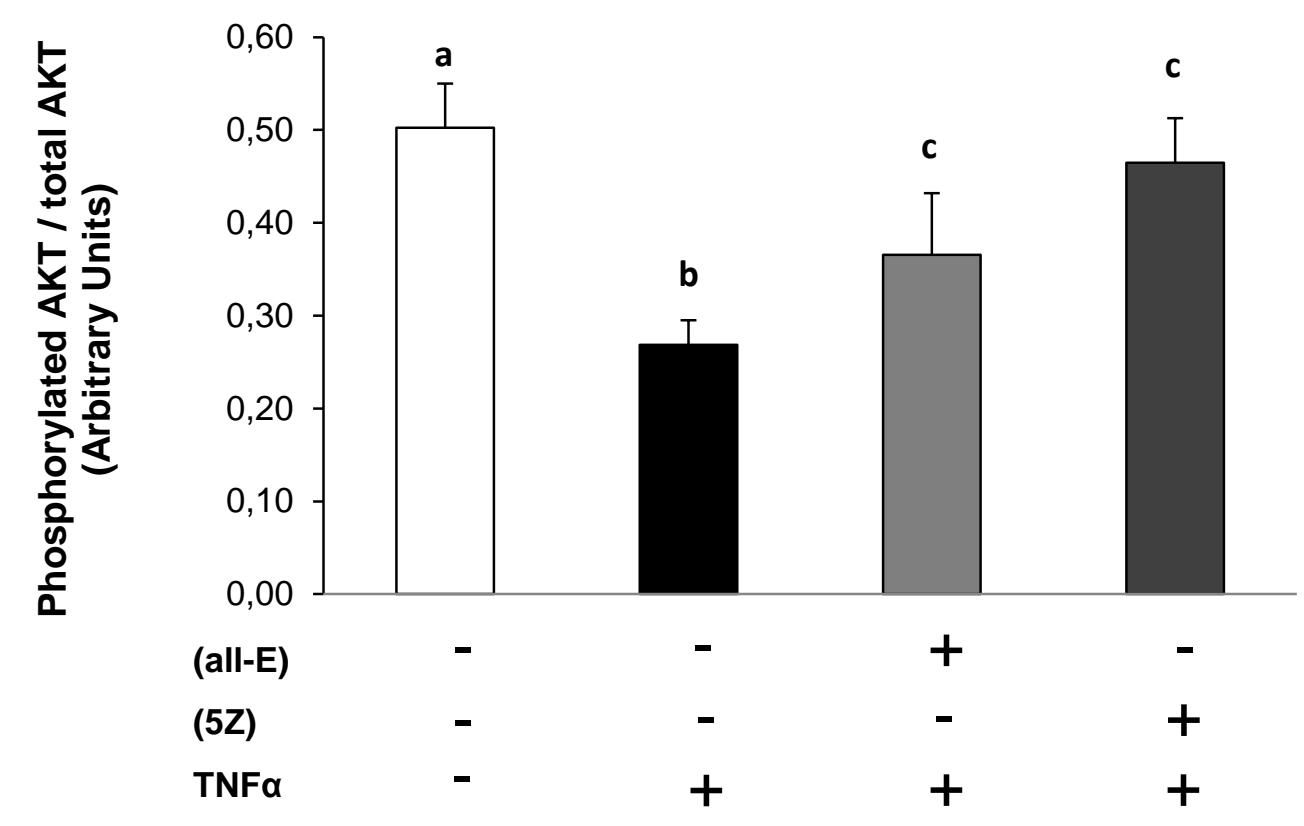

